\title{
PLANK ROADS IN NORTHEASTERN IOWA
}

Recently evidence has come to light of a plank road activity in the vicinity of Dubuque about which little had hitherto been known. As a fine supplement to the article of Mr. Remley J. Glass on the plank roads of Iowa which appeared in the January issue, the report of the Board of Directors of the Dubuque and Sageville Plank Road Company is given below, as it appeared in the Dubuque Weekly Miners Express of July 28,1852 . For some reason this company was never incorporated by an act of the state legislature, although they did actually build and operate a portion of the road. A portion of the road, at least, was in use as late as 1854 , as is indicated by an advertisement of an omnibus service of September 13, 1854 , in the same Dubuque paper. The proprietor of the line stated that he was ready to carry passengers "regularly between Waples House [a hotel] and Davis' farm, on the Plank Road." The fare charged was five cents cach way.

\section{REPORT}

The President and Directors of the Dubuque and Sageville Plank Road Company report, that two hundred and twentyone shares of stock have been taken, which, at twenty-five dollars per share, makes the sum of five thousand five hundred and twenty-five dollars. The first instalment of five per cent on each share was paid soon after the organization of the company and of the second, third, and fourth instalments of twenty per cent on each share, the sum of two thousand six hundred and forty-five dollars has been paid, making in all received up to this time, the sum of two thousand nine hundred twenty-one dollars and twenty-five cents. So soon after the organization of the company as practicable, we employed J. C. Jennings as engineer, to survey and locate the road. License having been granted by the County Court of Dubuque to construct a plank road, and to use for such purpose thirty feet of the public highway leading from Dubuque to Sageville, the engineer was instructed to locate it on the west half of the public highway, which was done. Immediately after the road was located, the distance, $41 / 2$ miles, was divided into three sections, and proposals issued through the newspapers of 
this city, for the earth work. The first section commencing at the north line of the corporation, and terminating at or near the north west corner of John E. Miller's enclosure, was taken by M'Gowen and Tool at 12 cts per square yard, for excavation and embankments, which, together with the work on culverts, walls, and extra work, amounts to the sum of six hundred twenty-two dollars and fifty-one cents.

The second section terminating a few rods north of Capt. Smith's barn was let to M'Gowen and Welch at 12 cts. per square yard, for excavations and embankments, which together with the work on culverts and extra work, amounts to the sum of eight hundred seventeen dollars and eight cents.

The third section was let to Patrick Sherman at 18 cents per square yard, for excavations and embankments, which, together with work on culverts and extra work, amounts to the sum of fifteen hundred and four dollars (and) ninety-four cents.

The contractors on the first and second sections have been paid in full, and nine hundred fifty-three dollars and fiftyfive cents have been paid to the contractor on the third section, leaving a balance due him of five hundred and fifty-one dollars thirty-nine cents. The road bed was ready for the plank about the first of January last, but owing to the great difficulty in getting plank, we have as yet been able to lay only about $1 / 4$ of a mile.

A contract has been entered into with L. Maloney to furnish three inch oak plank at eleven dollars per thousand, delivered on the landing in this city. About twenty-six thousand feet have been delivered and laid, and we are daily in the expectation of the receipt of one hundred and fifty thousand feet more, and the balance to complete the road can probably be delivered as fast as it may be wanted.

The following estimate will show the probable cost per mile: Earth work, including extra earth work, bridges, culverts, \&c $\$ 1060.00$

Plank, including sleepers, board measure, $160 \mathrm{M}$ feet at $\$ 11.00$ per $\mathrm{M}$ 1760.00 
Shaping and laying at $\$ 1$ per rod

It will be thus seen, that when this work was commenced, we knew nothing about plank roads, and made our estimates too low (for we did not estimate the cost at more than $\$ 2200$ per mile) or that we have paid much too high for work and materials, and yet, when we look at the cost of plank roads in the east, and compare the price of labor and lumber here with it there, the difference is not so great.

The Syracuse and Central Square Plank Road, 16 miles long, cost $\$ 1487$ per mile, with lumber at $\$ 5.10$ per M.

The Rome and Oswego road, 62 miles, cost about $\$ 1300$ per mile, with lumber at from $\$ 4$ to $\$ 5$ per $M$.

The lumber in each of these roads is hemlock, which can be afforded cheaper, but is far inferior to oak. The cost of their excavations and embankment was from ten to fifteen cents ; on ours, twelve, except on the $3 \mathrm{~d}$ section, where to form embankments a large portion of the earth was carried over 100 feet; in such cases, the price is usually doubled; the price on this section was 18 cents per yard. All the work was examined and measured by the engineer. We cannot believe that plank roads can be properly constructed in this country for less than the above estimate, unless the savings shall be in the price of lumber, which is more than double that of eastern prices. There may have been, and probably is, some superfluous ditching on the road, but, being inexperienced in work of this kind, we have thought it best to err on the safe side, and to make the road everything it should be, for strength and durability, and for rapidity, safety and economy of carriage; and we think these ends have been obtained. If completed on the plan proposed, there will probably not be so well built a road in the West. It will last for twelve or fifteen years, with an expenditure of not more than $\$ 10$ per mile annually for repairs.

It will yield the first year, at a moderate charge for toll, not less than 10 per ct. After the first year, while the cost of repairs will not be increased until the first superstructure is 
worn out, the profits will be increased in the ratio of the increase of travel.

Believing that the road will-be of great public utility, and an index to the enterprise of our eitizens, we would urgently recommend that it should be carried forward with prudence and energy to an early completion.

The capital stock of the company is now only eight thousand dollars, it should be increased to fifteen thousand. Several stockholders have paid only the first instalment of five per cent, and some the second, but the great majority have paid the 4 th.

The 5th was called for the first of this month; of this but about $\$ 20$ have been paid in.

\section{RECAPITULATION.}

Amount of stock subscribed, two hundred and twenty-

one shares at $\$ 25$ per share

Amount paid in

Amount paid out for work

Amount due contractor on $3 \mathrm{~d}$ sec.

Amount sec for about 26,000 (ft) lum-

ber at $\$ 11$ per $\mathrm{m}$.

286.00

Amount lumber additional culvert's and

laying, about 75 rod of plank, about

180.00

$\$ 1,017.39$

Respectfully submitted,

$$
\left.\begin{array}{l}
\text { J. J. Dycr } \\
\text { J. P. Farley } \\
\text { Platt Smith } \\
\text { L. Naloney } \\
\text { H. Thompson }
\end{array}\right\} \text { Directors }
$$

Mr. Remley J. Glass, has placed on our desk some information ' relating to the construction of a plank road across part of the Arizona desert, from Yuma to the Imperial Valley, California, which interestingly shows the vitality of the idea of wooden highways. In 1912 the business men of California in an effort to provide easier access to California for the motorist, laid two parallel strips of twelve inch planks across the

'The Buick Magazine. June, 1939. 
sands. This plank road was maintained until 1916, when the California State Highway Commission replaced this abbreviated plank road with a solid plank highway, made of railway ties. Though a better road, it was harder to handle in the shifting sands of the desert. Eventually, in 1925, a study of the shifting sands and the development of modern highway engineering succeeded in constructing a cement highway between the two points, still in suceessful use. .

\section{Stage Conch Notices}

Capt. Frye, of the Iowa House, has recently brought to this place, an excellent nine passenger, four horse Troy built post coach, with the intention of running it between this place and Iowa City as often as may be required.

Delegates [to a Democratic convention at Iowa City] from a distance, who may wish to travel by the river, will find no inconvenience in obtaining conveyances to the City The stable of. Mr. St. John is supplied with good and easy carriages in abundance for the probable demand.-Bloomington Herald, (Muscatine), May 28, 1841. 
Copyright of Annals of Iowa is the property of State of Iowa, by \& through the State Historical Society of Iowa and its content may not be copied or emailed to multiple sites or posted to a listserv without the copyright holder's express written permission. However, users may print, download, or email articles for individual use. 